\title{
Socioecological Impact of Mangrove Ecosystem in Kupang Bay, West Timor, Indonesia
}

\author{
Mouritz S. Sulaiman ${ }^{1 *}$, Fonny J. L. Risamasu ${ }^{1,2}$ and Frans K. Duan ${ }^{1,3}$
}

${ }^{1}$ Program Study of Environmental Sciences, Postgraduate Program,University of Nusa Cendana, Indonesia

${ }^{2}$ Faculty of Fisheries and Marine Science, University of Nusa Cendana, Indonesia

${ }^{3}$ Faculty of Science and Engineering, University of Nusa Cendana, Indonesia

DOI: $10.36347 /$ sajb.2020.v08i06.002

| Received: 01.06.2020 | Accepted: 09.06.2020 | Published: 13.06.2020

*Corresponding author: Mouritz S. Sulaiman

Abstract

Original Research Article

This study aims to determine the socioecological impact of mangrove ecosystems on the coastal communities in Oesapa Village and Tanah Merah Village, Kupang Bay. The method used to retrieve data in this study is the method of observation and interviews. Socioecological data on the use of mangrove ecosystems were analyzed using descriptive analysis, then data on socioecological impacts of mangrove ecosystems were analyzed by chi-square test $\left(\mathrm{X}^{2}\right)$, while the relationship of socioecological impact of mangrove ecosystems on coastal communities in Kupang Bay was analyzed using simple correlation analysis. The results of this study indicate that the social impact of mangrove ecosystems on coastal communities in Kupang Bay is the use of mangroves as fuel and building materials, boat landing areas, fishing ground shells, crabs, and shrimp and mangrove ecotourism. Furthermore, the ecological impact of mangrove ecosystems on coastal communities in Kupang Bay consists of utilization as a coastal protector from wave or wave abrasion, spawning ground and nursery ground for fish, shrimp and shellfish seeds, sediment traps from the land, nutrient providers for life and growth biota, and a place for birds to nest. Chi-square test results showed that the mangrove ecosystem in Kupang Bay based on community perceptions, had no significant social impact $(\mathrm{P}>0.05)$ for the local community, but had significant ecological impact $(\mathrm{P}<0.05)$. However, there was a strong relationship $(\mathrm{P}>0.05)$ between the mangrove ecosystem and the socioecological impacts in Kupang Bay.

Keywords: Socioecological, Mangrove, Ecosystem, Coastal, Community.

Copyright @ 2020: This is an open-access article distributed under the terms of the Creative Commons Attribution license which permits unrestricted use, distribution, and reproduction in any medium for non-commercial use (NonCommercial, or CC-BY-NC) provided the original author and source are credited

\section{INTRODUCTION}

Mangrove ecosystem is a tropical coastal vegetation community that dominated by several species of mangroves. Mangroves are able to grow and develop in muddy coastal tides. This vegetation community generally grows in tidal areas that are well watered and protected from large waves and strong tidal currents. Therefore, mangrove forests are found mostly on the shores of shallow bays, estuaries, deltas and protected coastal areas [1].

The ecological function of the mangrove ecosystem is as a fish spawning place in the waters, binding sediment dissolved from rivers, maintaining the balance of coastal ecosystems, minimizing coastal erosion or abrasion, protecting the land from wind, intrusion filtering sea water to the mainland and heavy metal content that andgerous for life, a high nutrient contributor to the flora and fauna that live in the area, a place for bird migration and as a wildlife habitat which is then used by humans for economic improvement. In addition to ecological functions, mangrove ecosystems also provide social functions both directly and indirectly for humans. For example, it can be used as firewood, building materials, chip raw materials, medicines, and fisheries [2].

The damage of mangrove ecosystems in the Oesapa and Tanah Merah Villages caused by human activities such as waste disposal, deforestation mangrove for firewood and building materials, fishing boat anchored activities, opening of salt ponds, catching biota in the mangrove areas. These various activities are likely to have an impact on the damage to mangrove ecosystems, and then cause the loss of ecological functions of mangroves for living and associated biota as well as the loss of social functions for the people who live in the vicinity [3]. This is evidenced through the results of a field survey at a location that found mangrove forest areas that were empty as a result of logging to obtain firewood and also logging for the 
opening of the fishing boat anchored area. Another thing was also found through the results of interviews conducted with the people at the location stating that in the past if the condition of the mangrove forest was still good or natural it could make a positive contribution to the maximum fisheries resources, in this case the number of catches such as crabs, shellfish, shrimp and others for the people in this location.

At present the increasing number of damaging activities in the mangrove ecosystem, it gives an impact on the lower contribution of fisheries resources to the community in this location in this case the number of catches is getting lower and even some of the people in this location have begun to expand to carry out activities of capturing biota such as crabs, shellfish and shrimp to the other village (Pariti Village), because according to them the number of catches obtained is very low. The magnitude of the damage to the mangrove forest is clearly seen from the traces of logging in the middle of the mangrove forest. Besides that, there was also an empty area of the former location of the pond where previously the area was overgrown with mangroves and open land with the remnants of mangrove stands.

Conditions as described above, indicate that there have been certain changes in the mangrove ecosystem as a result of unbalanced usage patterns and also as a result of certain pressures exerted by the local community, so as to result in a decrease in resource potential fisheries and also continued to the loss of socioecological benefits for the people at this location. Therefore, there is a need for management efforts for the sustainability of mangrove ecosystems for the lives of people in the region. However, to reach the point of maximum management, a variety of accurate data and information is needed, so by conducting research on the socioecological impact of the use of mangrove ecosystems for the communities in the Oesapa and Tanah Merah Villages of Kupang Bay is considered important to achieve this equilibrium.

\section{MATERIALS AND METHODS}

This research was conducted in November 2015 to January 2016, in the coastal areas of Oesapa and
Tanah Merah Villages, Kupang Bay. The tools and materials used in this study were transects, writing instruments, meter roll, digital camera, GPS, determinant book, refractometer, thermometer and $\mathrm{pH}$ meter. Species and sources of data to be obtained in this study are primary data and secondary data. Primary data is data obtained based on direct observations in the field (research location) which includes data on the condition of mangrove vegetation, mangrove community structure and social conditions of the community. Whereas secondary data was obtained through literature books, journals/proceedings and research report related to this research.

The acquisition of primary data related to ecological conditions through direct observation of the condition of vegetation and the structure of the mangrove community was carried out using the transect method, where at each of the five locations each transect was determined. The coordinates of each transect in the Oesapa coastal region are transects I: $\mathrm{S}=10^{\circ} 8^{\prime} 47.51^{\prime \prime}$ and $\mathrm{E}=123^{\circ} 38^{\prime} 33.22^{\prime \prime}$, transect II: $\mathrm{S}=10^{\circ} 8^{\prime} 47.43^{\prime \prime}$ and $\mathrm{E}=123^{\circ} 38^{\prime} 36.41^{\prime \prime}$, transect III: $10^{\circ} 8^{\prime} 48.87^{\prime \prime}$ and $\mathrm{E}=$ $123^{\circ} 38^{\prime} 39.68^{\prime \prime}$, transect IV: $\mathrm{S}=10^{\circ} 8^{\prime} 49.57^{\prime \prime}$ and $\mathrm{E}=$ $123^{\circ} 38^{\prime} 42.82^{\prime \prime}$, transect $\mathrm{V}: \mathrm{S}=10^{\circ} 8^{\prime} 48.72^{\prime \prime}$ and $\mathrm{E}=$ $123^{\circ} 38^{\prime} 49.96^{\prime \prime}$. Furthermore, the transects in the coastal area of The Tanah Merah Village are in the following coordinate position, transect $\mathrm{I}: \mathrm{S}=10^{\circ} 6^{\prime} 18.03^{\prime \prime}$ and $\mathrm{E}=$ $123^{\circ} 43^{\prime} 26.22^{\prime \prime}$, transect II: $\mathrm{S}=10^{\circ} 6^{\prime} 17.09^{\prime \prime}$ and $\mathrm{E}=$ $123^{\circ} 43^{\prime} 31.71^{\prime \prime}$, transect III: $\mathrm{S}=10^{\circ} 6^{\prime} 15.59^{\prime \prime}$ and $\mathrm{E}=$ $123^{\circ} 43^{\prime} 36.58^{\prime \prime}$, transect IV: $\mathrm{S}=10^{\circ} 6^{\prime} 17.55^{\prime \prime}$ and $\mathrm{E}=$ $123^{\circ} 43^{\prime} 45.00^{\prime \prime}$, transect : $\mathrm{S}=10^{\circ} 6^{\prime} 16.03^{\prime \prime}$ and $\mathrm{E}=$ $123^{\circ} 43^{\prime} 48.99^{\prime \prime}$.

This study was using the line transect method, which amounts to five transects for each station. Furthermore, each transect is placed randomly in sample plots in the form of a square with a size of $10 \times 10 \mathrm{~m}$ totaling 3 sample plots with a distance between sample plots on the $10 \mathrm{~m}$ transect. The total number of sample plots or plots in all transects is 15 sample plots, then in each sample plot that has been determined, each mangrove plant species is determined by using an identification manual.

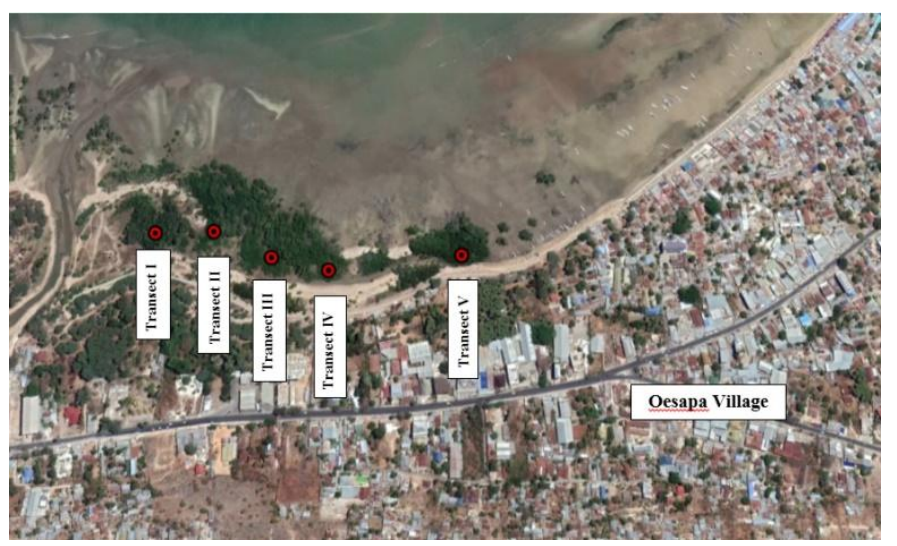




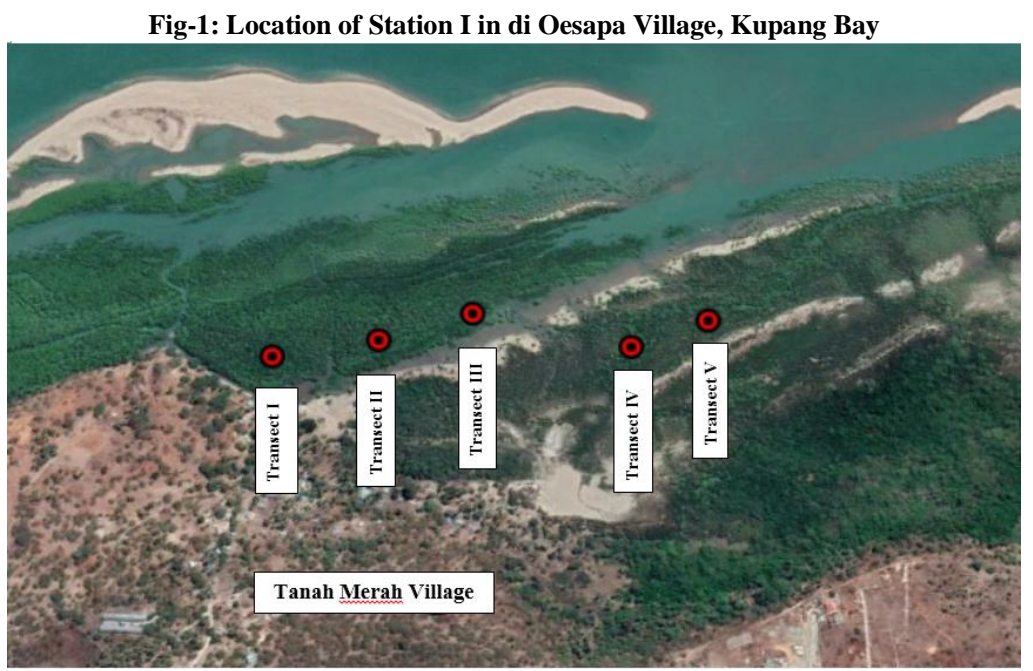

Fig-2: Location of Station II in Tanah Merah Village, Kupang Bay

Furthermore, the mangrove species that have been determined are counted by the number of individuals of each species and measured the height of the stems at chest height (about $1.3 \mathrm{~m}$ ), then the vegetation level measured is determined based on the diameter measured by the provisions of diameter pattern (trees, diameter $\geq 10 \mathrm{~cm}$ and height $>10 \mathrm{~m}$, saplings, diameter $<10 \mathrm{~cm}$ and height $1.5 \mathrm{~m}$ to $<10 \mathrm{~m}$, seedlings less than $1.5 \mathrm{~m}$ tall). Then the acquisition of primary data related to the social conditions of the communities in the two research sites in Kupang Bay, namely the coast of the Oesapa Village and Tanah Merah Village, was conducted using interview techniques to several community samples obtained through the "cluster random sampling" method, where all populations are considered to have the opportunity the same to be sampled. Based on the above provisions, the sample / respondent that will be used as the object of research is taken at random to represent the study location for the Oesapa Village with 40 samples/respondent and the Tanah Merah Village with 40 respondents. Data obtained from observations and interviews were then collected and analyzed to determine the socioecological impact of the utilization of mangrove ecosystems.

\section{Analysis of Mangrove Ecological Condition}

Data collected from observations calculated the value of species density, relative density, frequency of species, relative frequency, species closure, relative closure, and index value important to determine the condition of vegetation, while for the value of the community structure can be known from the results of the calculation of the diversity index value by following Shanon-Winer diversity index formula.

\section{a) Density (Di)}

Mangrove species density values can be calculated using the formula:
Where:

Di $=$ density of the $i^{\text {th }}$ species

$\mathrm{Ni}=$ total number of individu of the $\mathrm{i}^{\text {th }}$ species

$\mathrm{A}=$ total area sampling/plot

b) Relative Density (RDi)

The relative density value of mangrove species can be calculated using the formula:

$$
\mathrm{RDi}=\frac{\mathrm{ni}}{\sum \mathrm{n}} \times 100 \%
$$

Where:

$\mathrm{RDi}=$ relative density of the $\mathrm{i}^{\text {th }}$ species

ni $=$ total number of the $\mathrm{i}^{\text {th }}$ species

$\sum \mathrm{n} \quad=$ total stand of all species

\section{c) Frequency Species (Fi)}

Mangrove species frequency values can be calculated using the formula:

Where:

$$
\mathbf{F i}=\frac{\mathbf{p i}}{\sum \mathbf{p}}
$$

$\mathrm{Fi} \quad=$ frequency of the $\mathrm{i}^{\text {th }}$ species

pi = total sampling/plot where found the $\mathrm{i}^{\text {th }}$ species

$\sum \mathrm{p}=$ total sampling/plot of the whole species

\section{d) Relative Frequency (FRi)}

The relative frequency value of mangrove species can be calculated using the formula:

Where:

$$
\mathrm{RFi}=\frac{\mathrm{Fi}}{\sum \mathrm{F}} \times 100 \%
$$

$\mathrm{RFi}=$ relative frequency of the $\mathrm{i}^{\text {th }}$ species

$\mathrm{Fi} \quad=$ frequency of the $\mathrm{i}^{\text {th }}$ species

$\sum \mathrm{F} \quad=$ total number of sampling plots

$$
\text { Di }=\frac{n i}{A}
$$


e) Closure ( $\mathrm{Ci}$ )

Mangrove species cover values can be calculated using the formula:

Where:

$$
\mathbf{C i}=\frac{\sum \mathbf{B A}}{\mathbf{A}}
$$

$\mathrm{Ci}=$ closure of the $\mathrm{i}^{\text {th }}$ species

$\mathrm{BA}=$ basal area $\left[\boldsymbol{\pi} \mathrm{DBH}^{2} / 4\left(\right.\right.$ in $\left.\left.\mathrm{cm}^{2}\right)\right]$

$\mathrm{DBH}=$ total of the stem diameter of the $\mathrm{i}^{\text {th }}$ species

$[\mathrm{CBH} / \boldsymbol{\pi}$ (in $\mathrm{cm})]$

$\mathrm{A}=$ total area sampling/plot

$\mathrm{CBH}=$ Tree circumference as high as $1,3 \mathrm{~m}$

$\pi \quad=$ a constant $(3.1416)$

\section{f) Relative Closure ( $R C i$ )}

The relative closure value of mangrove species can be calculated using the formula:

Where:

$$
\mathrm{RCi}=\frac{\mathrm{Ci}}{\sum \mathrm{C}} \times 100 \%
$$

$\mathrm{RCi}=$ relative closure of the $\mathrm{i}^{\text {th }}$ species

$\mathrm{Ci}=$ closure of the $\mathrm{i}^{\mathrm{th}}$ species

$\sum \mathrm{C}=$ total closure of all species

\section{g) Important Value Index (IVI)}

The importance index of mangrove species can be calculated using the formula:

$$
\begin{aligned}
& \mathbf{I V I}_{\text {Trees }}=\mathbf{R D}_{\mathbf{i}}+\mathbf{R F}_{\mathbf{i}}+\mathbf{R C}_{\mathbf{i}} \\
& I V I_{\text {Saplings }}=\mathbf{R D}_{\mathbf{i}}+\mathbf{R F _ { i }}+\mathbf{R C}_{\mathbf{i}} \\
& I V I_{\text {Seedlings }}=\mathbf{R D}_{\mathrm{i}}+\mathbf{R F}_{\mathrm{i}}
\end{aligned}
$$

The importance of a mangrove species on the sapling level ranges from 0-300 and seedlings level 0-200. This Important Value provides an overview of the influence or role of a mangrove plant species in a mangrove community.

\section{h) Diversity Index $\left(H^{\prime}\right)$}

Mangrove diversity index values can be calculated using the formula:

Where:

$$
H^{\prime}=-\sum_{1=1}^{s} P i \ln P i
$$

$\mathrm{H}^{\prime} \quad$ = diversity index

$\mathrm{Pi} \quad=n i / \mathrm{N}$

ni $\quad=$ Total of individu of the $i^{\text {th }}$ species

$\mathrm{N} \quad=$ Total number of the whole individu

Category for diversity index is referring to the Table 1:

Table-1: Category for Diversity Index

\begin{tabular}{|c|c|c|c|c|c|}
\hline & Very Low & Low & Moderate & High & Very High \\
\cline { 2 - 6 } & $\mathbf{1}$ & $\mathbf{2}$ & $\mathbf{3}$ & $\mathbf{4}$ & $\mathbf{5}$ \\
\hline Diversity Index $\left(\mathrm{H}^{\prime}\right)$ & $\leq 1,75$ & $1,76-2,25$ & $2,26-2,75$ & $2,76-3,25$ & $\geq 3,26$ \\
\hline
\end{tabular}

\section{i) Uniformity Index (E)}

The uniformity index formula according to the following [4]:

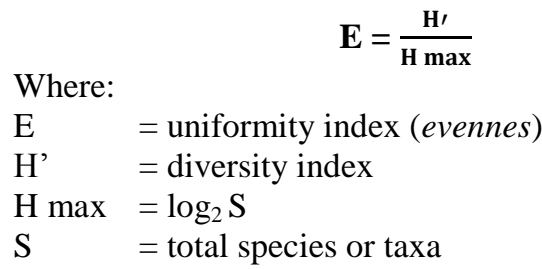

The index value of uniformity of this species ranges from $0-1$. When the uniformity index approaches 0 , then in the ecosystem there is a tendency for species domination to occur due to the instability of environmental and population factors. If the uniformity index value is close to 1 , then the ecosystem is in a relatively even condition i.e. the number of individuals for each species is relatively similar and the difference is not too striking [4].

\section{j) Dominance}

The dominance of certain species can be determined by using the Simpson Dominance Index as follows [4]:
Where:

$$
\mathbf{D}=\sum\left[\frac{(\mathbf{n i}-\mathbf{1})}{(\mathbf{N}-\mathbf{1})}\right]^{2}
$$

$\mathrm{D}=$ dominance

ni $\quad=$ Total of individu of the $i^{\text {th }}$ species

$\mathrm{N} \quad=$ Total number of the whole individu

The dominance index value ranges from $0-1$. If the dominance index value approaches 0 , it means that no individual dominates and is usually followed by a large uniformity index value. If the dominance index value is close to 1 it means that there is one genus that dominates and is usually followed by a small uniformity index value [5].

\section{Analysis of Socioecological Impact}

Analysis of the socioecological impact of mangrove ecosystems on communities in the coastal areas of Oesapa and Tanah Merah Villages was carried out using the Guttman rating scale of interviews about the knowledge and use of mangrove ecosystems. Furthermore, the results of the assessment will be tested using Chi-square analysis $\left(\mathrm{X}^{2}\right)$ to find out how much influence the socioecological impact of mangroves on the lives of the people in the location. 


$$
\mathbf{X}^{2}=\sum \frac{(\mathbf{f 0}-\mathbf{f e})^{2}}{\mathbf{f e}}
$$

Where:

$\mathrm{X}^{2}=$ chi-kuadrat value

$\mathrm{f}_{\mathrm{o}} \quad$ observed frequency (empirical frequency)

$\mathrm{fe}=$ expected frequency (theoritical frequency)

\section{Relationship of Socioecological Impacts on Coastal Communities}

Analysis of the relationship of the socioecological impacts of mangrove ecosystems on communities in the Oesapa and Tanah Merah coastal areas is done using simple correlation analysis:

$$
r=\frac{n \sum \mathbf{X Y}-\sum \mathbf{X} \sum \mathbf{Y}}{\sqrt{\mathbf{n} \sum \mathbf{X}^{2}-\left(\sum \mathbf{X}\right)^{2}} \sqrt{\mathbf{n} \sum \mathbf{Y}^{2}-\left(\sum \mathbf{Y}\right)^{2}}}
$$

Where:

$\mathrm{r}=$ corelation coefisien

$\mathrm{X}=$ independent variable

$\mathrm{Y}=$ dependent variable

\section{RESULTS AND DISCUSSION \\ Ecological Condition of Mangrove}

Mangrove in Oesapa Village consists of four species, namely Sonneratia alba, Avicennia alba, Rhizophora stylosa and Rhizophora mucronata. Furthermore, in Tanah Merah Village consists of six species, namely Sonneratia alba, Rhizophora mucronata, Rhizophora stylosa, Avicennia alba, Ceriops tagal and Bruguiera gymnorhitza. The species of mangroves based on their ecological condition of tree, sapling and seedling levels showed in Tables 2 to 4 .

\begin{tabular}{|c|c|c|c|c|c|c|c|}
\hline \multirow[t]{2}{*}{ Location } & \multirow[t]{2}{*}{ Variables } & \multicolumn{6}{|c|}{ Species of Mangrove } \\
\hline & & $S a$ & $A a$ & $\boldsymbol{R s}$ & $R m$ & $C t$ & $B g$ \\
\hline \multirow[t]{7}{*}{ Oesapa Village } & Di (Ind/ha) & 54 & 12 & 4 & 6 & - & - \\
\hline & RDI (\%) & 68.98 & 15.82 & 4.79 & 10.41 & - & - \\
\hline & $\mathrm{Fi}$ & 0.89 & 0.44 & 0.44 & 0.22 & - & - \\
\hline & RFI (\%) & 45.40 & 22.54 & 20.95 & 11.11 & - & - \\
\hline & $\mathrm{Ci}\left(\mathrm{m}^{2} / \mathrm{ha}\right)$ & 16.82 & 6.11 & 1.00 & 3.86 & - & - \\
\hline & $\mathrm{RCI}(\%)$ & 71.25 & 14.31 & 4.56 & 8.88 & - & - \\
\hline & IVI & 185.62 & 53.67 & 30.30 & 30.41 & - & - \\
\hline \multirow[t]{7}{*}{ Tanah Merah Village } & Di (Ind/ha) & 153 & 99 & 93 & 22 & 88 & 49 \\
\hline & RDI (\%) & 30.50 & 19.74 & 18.28 & 4.29 & 17.40 & 9.79 \\
\hline & $\mathrm{Fi}$ & 1.00 & 1.00 & 1.00 & 0.89 & 1.00 & 0.89 \\
\hline & RFI (\%) & 17.32 & 17.32 & 17.32 & 15.36 & 17.32 & 15.36 \\
\hline & $\mathrm{Ci}\left(\mathrm{m}^{2} / \mathrm{ha}\right)$ & 87.94 & 59.79 & 51.49 & 10.90 & 50.24 & 26.66 \\
\hline & RCI (\%) & 30.57 & 20.87 & 17.90 & 3.78 & 17.46 & 9.42 \\
\hline & IVI & 78.39 & 57.93 & 53.50 & 23.43 & 52.18 & 34.57 \\
\hline
\end{tabular}

Table-2: Ecological Condition of Mangrove on Trees Level

\begin{tabular}{|c|c|c|c|c|c|c|c|}
\hline \multirow[t]{2}{*}{ Location } & \multirow[t]{2}{*}{ Variables } & \multicolumn{6}{|c|}{ Species of Mangrove } \\
\hline & & $S a$ & $A a$ & $R s$ & $R m$ & $C t$ & $B g$ \\
\hline \multirow[t]{7}{*}{ Oesapa Village } & Di (Ind/ha) & 19 & 5 & 21 & 13 & - & - \\
\hline & RDI (\%) & 36.53 & 11.35 & 34.72 & 17.39 & - & - \\
\hline & $\mathrm{Fi}$ & 0.67 & 0.33 & 0.44 & 0.22 & - & - \\
\hline & RFI (\%) & 38.89 & 22.22 & 27.78 & 11.11 & - & - \\
\hline & $\mathrm{Ci}\left(\mathrm{m}^{2} / \mathrm{ha}\right)$ & 0.93 & 0.77 & 0.37 & 0.21 & - & - \\
\hline & RCI (\%) & 46.83 & 28.27 & 19.59 & 5.31 & - & - \\
\hline & IVI & 122.25 & 61.84 & 82.09 & 33.82 & - & - \\
\hline \multirow{7}{*}{$\begin{array}{l}\text { Tanah Merah } \\
\text { Village }\end{array}$} & Di (Ind/ha) & 101 & 30 & 41 & 11 & 39 & 33 \\
\hline & RDI (\%) & 39.48 & 11.69 & 16.31 & 4.39 & 15.33 & 12.81 \\
\hline & $\mathrm{Fi}$ & 1.00 & 0.89 & 1.00 & 0.56 & 1.00 & 1.00 \\
\hline & RFI (\%) & 18.43 & 16.21 & 18.43 & 10.06 & 18.43 & 18.43 \\
\hline & $\mathrm{Ci}\left(\mathrm{m}^{2} / \mathrm{ha}\right)$ & 5.00 & 1.46 & 2.01 & 0.55 & 1.89 & 1.62 \\
\hline & RCI (\%) & 39.82 & 11.59 & 16.24 & 4.43 & 15.26 & 12.65 \\
\hline & IVI & 97.73 & 39.49 & 50.98 & 18.88 & 49.03 & 43.89 \\
\hline
\end{tabular}

Table-3: Ecological Condition of Mangrove on Saplings Level 
Table-4: Ecological Condition of Mangrove on Seedlings Level

\begin{tabular}{|c|c|c|c|c|c|c|c|}
\hline \multirow[t]{2}{*}{ Location } & \multirow[t]{2}{*}{ Variables } & \multicolumn{6}{|c|}{ Species of Mangrove } \\
\hline & & $S a$ & $A a$ & $R s$ & $R m$ & $C t$ & $B g$ \\
\hline \multirow[t]{5}{*}{ Oesapa Village } & Di (Ind/ha) & 27 & 7 & 3 & 17 & - & - \\
\hline & RDI (\%) & 60.82 & 10.25 & 8.93 & 20.00 & - & - \\
\hline & $\mathrm{Fi}$ & 0.67 & 0.33 & 0.22 & 0.11 & - & - \\
\hline & RFI (\%) & 50.00 & 25.00 & 16.67 & 8.33 & - & - \\
\hline & IVI & 110.82 & 35.25 & 25.60 & 28.33 & - & - \\
\hline \multirow[t]{5}{*}{ Tanah Merah Village } & Di (Ind/ha) & 140 & 21 & 30 & 8 & 24 & 40 \\
\hline & RDI (\%) & 53.55 & 8.36 & 11.38 & 3.01 & 9.15 & 14.55 \\
\hline & $\mathrm{Fi}$ & 0.89 & 0.78 & 0.89 & 0.56 & 0.89 & 0.89 \\
\hline & RFI (\%) & 18.11 & 15.88 & 18.11 & 11.70 & 18.11 & 18.11 \\
\hline & IVI & 71.66 & 24.24 & 29.48 & 14.71 & 27.26 & 32.65 \\
\hline
\end{tabular}

Abbreaviation description:

$\mathrm{Sa}$ : Soneratia alba

Aa : Avicennia alba

Rs : Rhizophora stylosa

$R m$ : Rhizophora mucronata

Ct : Ceriops tagal

Bg : Bruguiera gymnorhitza

Based on the value of density (Di), relative density ( $\mathrm{RDi}$ ), frequency (Fi), relative frequency (RFi), closure $(\mathrm{Ci})$, relative closure $(\mathrm{RCi})$ and important value index (IVI) showed that the highest ecological conditions of mangrove are found in Soneratia alba both in the Oesapa and Tanah Merah Villages. The ecological condition of mangrove vegetation illustrates the high and low domination of a mangrove species in its habitat. Mangrove vegetation conditions can also be seen from the value of species density (Di), relative density of species (RDi), frequency $(\mathrm{Fi})$ and relative frequency of species (RFi), closure (Ci) and relative closure of species (RCi) and important value index (IVI) which also describe the level of adaptation of a mangrove species to the habitat it grows $[2,6]$. Therefore, the Soneratia Alba species compared to other mangrove species on the coast of Oesapa Village and Tanah Merah Village, Kupang Bay shows that the Soneratia Alba dominates the mangrove ecosystem in the region.

The structure of mangrove communities in Oesapa Village showed that the diversity index were at the tree level of 0.345 , at the sapling level of 0.379 and at the seedling level of 0.312 , then the uniformity index were at the tree level of 0.681 , at the sapling level of 0.902 and at the seedling level of 0.728 , whereas the dominance index were at the tree level of 0.573 , at the sapling level of 0.457 and at the seedling level of 0.475 . In Tanah Merah Village, the diversity index were at the tree level of 0.716 , at the sapling level of 0.692 and at the seedling level of 0.598 , then the uniformity index were at the tree level of 0.920 , at the sapling level of 0.889 and at the seedling level of 0.768 , whereas the dominance index were at the tree level of 0.209 , at the sapling level of 0.240 and at the seedling level of 0.341 (Tables 5 to 7).

Table-5: Community Structure of Mangrove in Trees Level

\begin{tabular}{|c|c|c|c|c|c|c|c|c|}
\hline \multirow[t]{2}{*}{ Location } & \multirow[t]{2}{*}{ Variables } & \multicolumn{6}{|c|}{ Species of Mangrove } & \multirow[t]{2}{*}{ Total } \\
\hline & & $S a$ & $A a$ & $R s$ & $R m$ & $C t$ & $B g$ & \\
\hline \multirow[t]{3}{*}{ Oesapa Village } & Diversity Index $\left(\mathrm{H}^{\prime}\right)$ & 0.120 & 0.118 & 0.054 & 0.053 & - & - & 0.345 \\
\hline & Uniformity Index (E) & 0.209 & 0.247 & 0.114 & 0.110 & - & - & 0.681 \\
\hline & Dominance Index (D) & 0.510 & 0.027 & 0.004 & 0.033 & - & - & 0.573 \\
\hline \multirow{3}{*}{$\begin{array}{l}\text { Tanah Merah } \\
\text { Village }\end{array}$} & Diversity Index $\left(\mathrm{H}^{\prime}\right)$ & 0.157 & 0.139 & 0.134 & 0.057 & 0.132 & 0.098 & 0.716 \\
\hline & Uniformity Index (E) & 0.201 & 0.178 & 0.172 & 0.073 & 0.170 & 0.126 & 0.920 \\
\hline & Dominance Index (D) & 0.093 & 0.039 & 0.034 & 0.002 & 0.031 & 0.010 & 0.209 \\
\hline
\end{tabular}

Table-6: Community Structure of Mangrove in Saplings Level

\begin{tabular}{|c|c|c|c|c|c|c|c|c|}
\hline \multirow[t]{2}{*}{ Location } & \multirow[t]{2}{*}{ Variables } & \multicolumn{6}{|c|}{ Species of Mangrove } & \multirow{2}{*}{ Total } \\
\hline & & $S a$ & $A a$ & $R s$ & $R m$ & $C t$ & $B g$ & \\
\hline \multirow{3}{*}{ Oesapa Village } & Diversity Index $\left(\mathrm{H}^{\prime}\right)$ & 0.155 & 0.087 & 0.088 & 0.049 & - & - & 0.379 \\
\hline & Uniformity Index (E) & 0.388 & 0.183 & 0.228 & 0.103 & - & - & 0.902 \\
\hline & Dominance Index (D) & 0.143 & 0.019 & 0.204 & 0.091 & - & - & 0.457 \\
\hline \multirow{2}{*}{$\begin{array}{l}\text { Tanah Merah } \\
\text { Village }\end{array}$} & Diversity Index $\left(\mathrm{H}^{\prime}\right)$ & 0.159 & 0.109 & 0.128 & 0.059 & 0.124 & 0.113 & 0.692 \\
\hline & Uniformity Index (E) & 0.205 & 0.140 & 0.164 & 0.076 & 0.159 & 0.145 & $\mathbf{0 . 8 8 9}$ \\
\hline
\end{tabular}


Mouritz S. Sulaiman et al., Sch Acad J Biosci, June., 2020; 8(6): 143-152

Dominance Index (D)

\begin{tabular}{l|l|l|}
0.156 & 0.014 & 0.027 \\
\hline
\end{tabular}

0.002

0.024

0.017

0.240

Table-7: Community Structure of Mangrove in Seedlings Level

\begin{tabular}{|c|c|c|c|c|c|c|c|c|}
\hline \multirow[t]{2}{*}{ Location } & \multirow[t]{2}{*}{ Variables } & \multicolumn{6}{|c|}{ Species of Mangrove } & \multirow[t]{2}{*}{ Total } \\
\hline & & Sa & $A a$ & $R s$ & $R m$ & $C t$ & $B g$ & \\
\hline \multirow{3}{*}{$\begin{array}{l}\text { Oesapa } \\
\text { Village }\end{array}$} & Keanekaragaman $\left(\mathrm{H}^{\prime}\right)$ & 0.108 & 0.082 & 0.078 & 0.044 & - & - & 0.312 \\
\hline & Keseragaman (E) & 0.250 & 0.173 & 0.213 & 0.093 & - & - & 0.728 \\
\hline & Dominansi (D) & 0.429 & 0.016 & 0.018 & 0.012 & - & - & 0.475 \\
\hline \multirow{3}{*}{$\begin{array}{l}\text { Tanah Merah } \\
\text { Village }\end{array}$} & Keanekaragaman $\left(\mathrm{H}^{\prime}\right)$ & 0.145 & 0.089 & 0.107 & 0.045 & 0.094 & 0.118 & 0.598 \\
\hline & Keseragaman (E) & 0.186 & 0.114 & 0.138 & 0.058 & 0.120 & 0.151 & 0.768 \\
\hline & Dominansi (D) & 0.287 & 0.007 & 0.013 & 0.001 & 0.009 & 0.024 & 0.341 \\
\hline
\end{tabular}

Abbreaviation description:

$\mathrm{Sa}$ : Soneratia alba

Aa : Avicennia alba

Rs : Rhizophora stylosa

Rm : Rhizophora mucronata

Ct : Ceriops tagal

Bg : Bruguiera gymnorhitza

The structure of the mangrove community as seen from the mangrove diversity index at the tree, sapling and seedling level is classified as very low. Besides that, based on the value of uniformity and dominance index of mangrove species showed that species dominance to occur due to environmental changes due to increased human activity. Community structure is a variable in determining the dominance of species, the distribution patterns or the distribution of certain species of biota in the habitats [1]. The pattern of distribution and domination of mangrove communities in a habitat is very closely related to the condition of the habitat of biota [7]. If the habitat condition is in good or natural condition then the pattern of distribution and domination of biota is in a stable or balanced state. However, if the pattern of spread of a biota or plant in a habitat is unstable or unbalanced, it will have an effect on the disruption of the community structure of the biota or plant [3]. Therefore, based on this opinion, it can be seen that the unstable pattern of mangrove distribution and dominance or the instability of the mangrove community structure on the coast of Oesapa Village and Tanah Merah Village, Kupang Bay is due to the condition of the habitat in this area that has been disturbed or certain pressures which then have an effect on the low or changing conditions of existing mangrove communities in this region as a result of various activities from the mainland such as the disposal of detergent waste from the laundry that enters the mangrove habitat and also the activities that exist within the mangrove forest in the use of mangroves such as the cutting of mangroves for firewood and the opening of the area to anchor fishing boats, the disposal of waste, catching of biota in the area which causes the low quality of the environment as mangrove habitat in these two regions.

\section{General Conditions of the Coastal Communities}

Community understanding on the coast of Oesapa Village and Tanah Merah Village towards the mangrove ecosystem according to the local community is one of the ecosystems that provides benefits for their lives including the mangrove ecosystem providing a variety of resources in it such as fish, crabs, shrimp and shellfish, so it is not surprising that the various exploitation or catching activities of existing biota to improve their economic level so that social welfare in life related to their daily needs. In addition, according to them the mangrove ecosystem also provides various other social benefits such as being able to withstand waves and waves coming from the ocean so that the existence of settlements or housing for people who live in coastal areas can be protected or not disturbed. However, that the most of coastal community often carry out certain activities such as felling mangrove trees for firewood needs, making the fishing boat landing area and also being used as a house pole, so it is not surprising the condition of the mangrove ecosystem in this area now has experienced a variety of certain degradation pressures so that the current effect is the occurrence of coastal abrasion and also the settlement and housing communities in the local area have also begun to be affected or disrupted by wave and wave activity as a result of the fewer mangrove trees that can withstand or reduce the waves in the coastal area of this area and even various resources such as fish, shrimp and crabs nowadays are very few that can have an effect also on the increasingly loss of social welfare for the coastal community in this area $[3,8]$.

Activities carried out in the coastal areas of the Oesapa village are catching biota (crabs and clams), fishing, fishing boat anchoring activities, recreational activities, domestic waste disposal and also other activities of the local government and other institutions which at certain times carry out mangrove planting. As for the coastal of the Tanah Merah Village are catching biota (crabs and clams), fishing, and also other activities such as fishing boat dockings. In addition, according to local communities both on the coastal of Oesapa and Tanah Merah used to exploit mangrove trees for certain needs such as firewood, house poles and some who used mangrove wood for the need for trawlers. 
Coastal area is a region that is very susceptible to various disturbances such as activities from the mainland which include the disposal of garbage and household waste that goes to the coastal and marine areas and also activities carried out directly in the coastal watershed itself such as ship docking activities and search for biota such as fish, crabs, shrimp and others at the lowest tide which is likely to contribute negatively to the degradation of the coastal and marine environment as a habitat for biota such as mangrove ecosystems. The life of coastal biota such as crabs, clams, shrimp and fishes is very dependent on the good and bad environmental conditions in this case the mangrove ecosystem as its habitat. If the condition of the mangrove ecosystem as its habitat is in good condition then its growth and survival will reach its maximum point. If the condition of the mangrove ecosystem as its habitat in a state of inadequate or bad, then will be impact on the decline in the number of population.

\section{Socioecological Impacts of Mangrove Ecosystems on Coastal Communities}

Socioecological impacts of the use of mangrove ecosystems for communities in the coastal areas of Oesapa and Tanah Merah Villages based on respondents assessment using the Guttman scale, show differences in the two locations.

Table-8: Social Impacts of Mangrove Ecosystems on Coastal Communities

\begin{tabular}{|c|c|c|c|c|}
\hline Location & Category & Guttman Scale & Frequency & Persentage \\
\hline \multirow{4}{*}{ Oesapa Village } & Impact & 1 & 24 & 60.00 \\
\cline { 2 - 5 } & No Impact & 0 & 16 & 40.00 \\
\cline { 2 - 5 } & Total & & $\mathbf{4 0}$ & $\mathbf{1 0 0}$ \\
\hline \multirow{4}{*}{ Tanah Merah Village } & Impact & 1 & 23 & 57.50 \\
\cline { 2 - 5 } & No Impact & 0 & 17 & 42.50 \\
\cline { 2 - 5 } & Total & $\mathbf{4 0}$ & $\mathbf{1 0 0}$ \\
\hline
\end{tabular}

Tabel-9: Ecological Impacts of Mangrove Ecosystems on Coastal Communities

\begin{tabular}{|c|c|c|c|c|}
\hline Location & Category & Guttman Scale & Frequency & Persentage \\
\hline \multirow{4}{*}{ Oesapa Village } & Impact & 1 & 37 & 92,5 \\
\cline { 2 - 5 } & No Impact & 0 & 3 & 7,5 \\
\cline { 2 - 5 } & Total & & $\mathbf{4 0}$ & $\mathbf{1 0 0}$ \\
\hline Tanah Merah Village & Impact & $\mathbf{1}$ & $\mathbf{3 8}$ & $\mathbf{9 5}$ \\
\cline { 2 - 5 } & No Impact & 0 & 2 & 5 \\
\cline { 2 - 5 } & Total & $\mathbf{4 0}$ & $\mathbf{1 0 0}$ \\
\hline
\end{tabular}

In Oesapa Village $60 \%$ of respondents said that mangrove ecosystems had a social impact on the community, while $40 \%$ of respondents answered they did not have a social impact (Table 9). Furthermore, based on the results of the chi-square test $\left(\mathrm{X}^{2}\right)$, it shows that the mangrove ecosystem is insignificant $\left(\mathrm{X}^{2}=1.6<\right.$ $\mathrm{X}_{\text {table }}=3.841$ or $\left.\mathrm{P}>0.05\right)$ giving social impacts to the community. Furthermore, in Tanah Merah Village $57.5 \%$ of respondents stated that mangrove ecosystems had a social impact on the community; while $42.5 \%$ of respondents answered that they did not have a social impact (Table 9). Furthermore, the results of the chi-square test $\left(\mathrm{X}^{2}\right)$, showed that mangrove ecosystems did not have a significant social impact $\left(\mathrm{X}^{2}=0.9<\mathrm{X}_{\text {table }}\right.$ $=3.841$ or $\mathrm{P}>0.05)$ for the community. Thus the mangrove ecosystem in Kupang Bay based on community perceptions, does not have a significant social impact on the local community.

In Oesapa Village $92.5 \%$ of respondents said that mangrove ecosystems had ecological impacts, while $7.5 \%$ of respondents answered that they did not have ecological impacts (Table 10). Furthermore, based on the results of the chi-square test $\left(\mathrm{X}^{2}\right)$, it shows that the mangrove ecosystem significantly $\left(X^{2}=28.9>X_{\text {table }}=\right.$
3.841 or $\mathrm{P}<0.05$ ) has an ecological impact. Furthermore, in Tanah Merah Village $95 \%$ of respondents stated that mangrove ecosystems had ecological impacts, while 5\% of respondents answered they did not have social impacts (Table 10). Furthermore, the results of the chi-square test $\left(\mathrm{X}^{2}\right)$, showed that the mangrove ecosystem had a significant ecological impact $\left(\mathrm{X}^{2}=\right.$ $32.4>\mathrm{X}_{\text {table }}=3.841$ or $\left.\mathrm{P}<0.05\right)$ for the community. Thus the mangrove ecosystem in Kupang Bay has a significant ecological impact.

Correlation analysis results of both the ecological and social impacts of the mangrove ecosystem showed that the value of $r=0.349>r_{\text {table }}=$ 0.320 ( $\mathrm{P}<0.05)$, so there is a strong relationship between the mangrove ecosystem and the socioecological impacts in Oesapa Village. Likewise, Correlation analysis results of both ecological and social impacts of mangrove ecosystems show that the calculated value of $r$ $=0.331>r_{\text {table }}=0.320(\mathrm{P}<0.05)$, so there was a strong relationship between the mangrove ecosystem and the socioecological impacts in Tanah Merah Village. Thus, there was a strong relationship between the mangrove ecosystem and the socioecological impacts in Kupang Bay. 
The existence and use of mangrove ecosystems in Kupang Bay are closely related to their ecological and social impacts in Kupang Bay, although the relationship between mangrove ecosystems and their socioecological impacts was not significant at this time. But for some coastal communities that have a source of income that is directly related to the existence of mangrove ecosystems, it will certainly have a positive impact on the sustainable management of mangrove ecosystems in this area.

The influence of ecological impacts on the social impacts of the mangrove ecosystem above, which can be seen from when there is damage from the mangrove ecosystem itself as a result of various activities such as the occurrence of degradation in the mangrove ecosystem. The sustainability of mangrove ecosystems in a habitat is strongly influenced by factors originating from internal factors (natural factors) and external factors (human activities) [9]. Internal factors that affect the life of mangroves can be either high or low speed of currents and waves. Where the higher the speed of currents and waves in a mangrove habitat it will give effect to the death of mangrove plants in this case at the level of seedlings in its development towards the level of saplings, saplings and trees, so that the effect is the lower number of mangrove individuals in the habitat. While external factors that affect the growth and life of mangroves in a habitat that can come from community activities originating from the mainland such as the disposal of garbage and waste to the sea and industrial activities and other anthropogenic activities. Furthermore, external factors that are in the mangrove ecosystem can be in the form of mangrove logging activities, boat landing activities, opening of the pond area and also the activity of capturing destructive biota in the mangrove ecosystem such as crab, shrimp, shellfish and others [10].

Human activities from the mainland affect the existence of mangrove ecosystems, such as dumping garbage into the sea directly will cause sedimentation and will also cover the mouth of mangrove leaves at the seedling level so that it will have an effect on the disruption of photosynthesis for mangrove plants for growth and survival towards the level saplings and go to the tree level which then impacts the occurrence of mangrove mortality at the seedling level and associated marine biota [6]. Activities in the form of waste disposal leading to coastal and marine areas will influence changes in substrate structure and nutrient composition for growth and survival of mangroves [3]. In addition, the existence of anchor fishing activities in the mangrove area will contribute negatively to the occurrence of oil spillage in the mangrove habitat which will then influence the changes in nutrient composition for mangrove growth and survival. Then the activities carried out directly in the mangrove ecosystem in the form of mangrove logging, can lead to a decrease in the number or composition of mangrove species. While benthic biota catching activities in mangrove ecosystems can affect changes in substrate structure and the amount of nutrient composition and result in low water fertility and environmental quality as mangrove habitat, thus impacting the disruption of growth and survival of mangroves and associated various biota $[3,11]$. Thus the decline in the socioecological function of the mangrove ecosystem will impact on the increasingly loss of socioecological impacts of the mangrove ecosystem itself for coastal communities. The development of mangrove ecotourism is a form of mangrove ecosystem management that has a positive impact on mangrove conservation efforts. Coastal communities who benefit directly from the presence of mangrove ecosystems will be more successful in participatory and sustainable management [12].

\section{CONCLUSION}

The socioecological impact of mangrove ecosystem on coastal communities in the coastal areas of Oesapa Village and Tanah Merah Village for social purposes consists of its use for fuelwood needs, building material needs, needs for house poles, needs for boat mooring areas, for areas to dispose of waste and rubbish, for areas looking for marine life such as shellfish, crabs, shrimp and other marine biota as well as for recreation areas. Furthermore, the ecological impact provided by the mangrove ecosystem for coastal communities in the Oesapa and Tanah Merah Villages of Kupang Bay, consists of its benefits as a coastal protector, coastal protector from abrasion, wave and wave dampers, a place for developing and sheltering for fish, shrimp and shellfish from off shore, traps of sediment or waste from land, providing nutrients for the life and growth of biota, nesting places for birds, habitat for many biota and shelter for various biota. The mangrove ecosystem in Kupang Bay has no significant social impact on the local community, but it have significant ecological impact. However there was a strong relationship between the mangrove ecosystem and its socioecological impacts in Kupang Bay.

\section{ACKNOWLEDGMENTS}

Acknowledgments the authors give to friends who have helped in the research process until the completion of writing this article including for Aludin $\mathrm{Al}$ Ayubi, S.Pi., M.Si., Muni Jitro Amtiran, S.Pi., M.Si, Sugianto Abdul Kadir and Trisutrisno Usman.

\section{REFERENCES}

1. Kerry RG, Das G, Patra JK. Biodiversity and conservation of Mangrove ecosystem around the World. Journal of Biodiversity and Conservation.2017; 1(1), 9-9.

2. Sambu AH, Rahmi, Khaeriyah A. Analysis of Characteristics of and Use Value of Mangrove Ecosystem (Case Study in Samataring and 
Tongketongke Sub-Districts, Sinjai Regency). Journal of Environment and Ecology. 2014; 5(2), 222-233.

3. Fredrik D, Santoso P, Alayubi A. Composition and structure of mangrove community on sapling and seedling levels in Coastal of Dolulolong, Lembata, Indonesia. International Journal of Biosciences.2019; 15(4), 153-160.

4. Brower J, Zar J, Von Ende C. General ecology, field and laboratory methods. Brown Company Publ. Dubugue. Iowa. 1989;3.

5. Odum EP. Fundamentals of Ecology. Third Edition. Wb. Sounder Company Ltd. Philadelphia.1971; 237-264.

6. Awn MSM, Yulianda F, Yonvitner. Characteristics and Above-Ground Biomass of Mangrove Species in Enggano Island, Bengkulu Sumatra, Indonesia. International Journal of Advanced Engineering, Management and Science (IJAEMS). 2016; 2(7): 1084-1091.

7. Lignon CM, Coelho CJ, Almeida R, Menghini PR, Schaeffer NY, Cintrón G, Dahdouh GF. Characterisation of Mangrove Forest Species in Wiew of Conservation and Management: a review of Mangals at the Cananéia region, São Paulo State, Brazil. International Journal of Coastal Research. 2011; 5(7), 349-353.

8. Awn MS, Yulianda F, Yonvitner Y. Characteristics and Above-Ground Biomass of Mangrove Species in Enggano Island, Bengkulu Sumatra, Indonesia. International Journal of Advanced Engineering, Management and Science. 2(7).

9. Hakim L, Siswanto D, Makagoshi N. Mangrove conservation in East Java: the ecotourism development perspectives. Journal of Tropical Life Science. 2017 Sep 11;7(3):277-85.

10. Krebs CJ.Ecology, the Experimental Analisys of Distribution and Abuandce Haper anda Row Publ. New York.2009; 496.

11. Utina R, Katili AS, Lapolo N, Dangkua T. The composition of mangrove species in coastal area of Banggai District, Central Sulawesi, Indonesia. Biodiversitas Journal of Biological Diversity. 2019 Mar 3;20(3):840-6.

12. Kusmana C, Sukwika T. Coastal community preference on the utilization of mangrove ecosystem and channelbar in Indramayu, Indonesia. AACL Bioflux. 2018;11(3):905-18. 